\title{
PURIFICATION AND CHARACTERIZATION OF AN AMINOGLYCOSIDE INACTIVATING ENZYME FROM STAPHYLOCOCCUS EPIDERMIDIS FK109 THAT NUCLEOTIDYLATES THE 4'- AND 4"'-HYDROXYL GROUPS OF THE AMINOGLYCOSIDE ANTIBIOTICS
}

\author{
P. SAntanam and F. H. Kayser \\ Institute of Medical Microbiology, University of Zürich \\ CH-8028 Zürich, Switzerland
}

(Received for publication December 22, 1977)

\begin{abstract}
The resistance to aminoglycoside antibiotics in Staphylococcus epidermidis FK109, is mediated by an enzyme that catalyzes transfer of the nucleotide monophosphate moiety from the nucleotide triphosphates, either to the 4'-hydroxyl group or to the 4"-hydroxyl group, that is in the equatorial plane of the aminoglycoside molecule. The enzyme, modifying the two sites, appears as a single and homogeneous entity in affinity chromatography, in chromatography on DEAE-Sepharose CL-6B, in isoelectric focusing and in gel-filtration. It requires divalent cations, notably $\mathrm{Mg}^{++}$, and dithiothreitol for optimal adenylylation. It has a molecular weight of 46,770 and an isoelectric point of 5.0. The ability of the enzyme ANT $\left(4^{\prime}, 4^{\prime \prime}\right)$ to modify the two hydroxyl groups of aminoglycoside molecules, enables it to have a spectrum of substrates that surpasses, in range, the substrate spectrum of all the aminoglycoside-modifying enzymes which have been characterized hitherto.
\end{abstract}

We reported occurence of an enzyme (tobramycin adenylyl-transferase) in Staphylococcus epidermidis FK109, mediating resistance to aminoglycoside antibiotics by adenylylation, probably of the 4'-hydroxyl group of the aminoglycoside molecule. ${ }^{1)}$ A similar enzyme has been reported to occur in Staphylococcus aureus, ${ }^{2)}$ resistant to multiple drugs. Experiments conducted subsequent to our report, revealed that the enzyme, probably, was capable of adenylylating the 4"-hydroxyl group of the aminoglycoside molecule, also. ${ }^{3)}$ In order to clarify whether adenylylation of the two hydroxyl groups was mediated by two different enzymes or a single enzyme, and to characterize the enzyme, purification of the enzyme was necessary. The experimental results and their inference are presented in this report.

\section{Materials and Methods}

\section{Antibiotics and Chemicals}

Tobramycin and apramycin were supplied by Eli Lilly and Co. (Indianapolis, Ind.); the kanamycins, lividomycins, butirosins, and amikacin were supplied by Bristol Laboratories (Syracuse, N.Y.); the neomycins were provided by Upjohn Co. (Kalamazoo Mich.); paromomycin was supplied by Parke, Davis and Co. (Detroit, Mich.); and the gentamicins and sisomicin were supplied by Schering Corp. (Bloomfield, N.J.).

Commercially available dibekacin $\left(3^{\prime}, 4^{\prime}\right.$-dideoxykanamycin B) was a gift from T. YокотA of Juntendo University (Tokyo, Japan) and a purified sample of the same drug was kindly provided by H. KaWABE of Gunma University (Maebashi, Japan). A sample of tobramycin 4'-AMP was provided by URSULA SCHWOTZER at our institute.

Radioactive chemicals were supplied by the Radiochemical Centre (Amersham, England). Cytochrome $\mathrm{C}, \alpha$-chymotrypsinogen $\mathrm{A}$, dithiothreitol, and unlabelled nucleotide-triphosphates were 
supplied by Calbiochem (Los Angeles, Calif.). Ovalbumin and bovine serum albumin (BSA) were supplied by Miles Laboratories, Inc. (Elkhart, Ind.). All other inorganic salts of analytical grade were supplied by E. Merck AG (Darmstadt, Germany).

\section{Purification of the Enzyme}

The enzyme was extracted from Staphylococcus epidermidis FK109 by the osmotic shock method described previously ${ }^{1,3)}$. The osmotic shockate was purified by affinity chromatography either with dibekacin or with tobramycin bound to cyanogen bromide activated Sepharose-4B (Pharmacia Fine Chemicals, Uppsala, Sweden), according to the manufacturer's instructions. A $0.9 \times 15 \mathrm{~cm}$ column (Pharmacia Fine Chemicals, Uppsala, Sweden) was packed with the dibekacin-bound gel suspended in buffer $\mathrm{A}$ that consisted of $0.02 \mathrm{M}$ Tris- $\mathrm{HCl}$ buffer, $0.01 \mathrm{M} \mathrm{MgCl}_{2}, 20 \%$ glycerine, $\mathrm{pH} 8.5$, and $0.01 \mathrm{M}$ dithiothreitol. The osmotic shockate $(35 \mathrm{ml}$, mixed with $10 \times$ concentrated buffer $\mathrm{A}$ to give a $\mathrm{pH}$ of 8.5) was applied to the column and the enzyme was eluted with a linear gradient of $\mathrm{NaCl}$ $(0 \sim 0.9 \mathrm{M})$ in buffer A. Fractions having enzymatic activity were pooled and concentrated to $10 \mathrm{ml}$ in a Diaflo apparatus with a PM-10 membrane (Amicon Corporation, Lexington, Mass.). The sample was pressure dialyzed with $300 \mathrm{ml}$ of buffer B that consisted of $0.02 \mathrm{M}$ Tris-maleate buffer, with $0.01 \mathrm{M} \mathrm{MgCl}_{2}, 20 \%$ glycerine, $\mathrm{pH} 7.0$, and $0.01 \mathrm{M}$ dithiothreitol, concentrated to $10 \mathrm{ml}$ and applied to a $0.9 \times 15 \mathrm{~cm}$ column packed with DEAE-Sepharose CL-6B (Pharmacia Fine Chemicals, Uppsala, Sweden). The enzyme was eluted with a gradient of $\mathrm{NaCl}(0 \sim 0.7 \mathrm{M})$ in buffer B. Fractions having enzymatic activity were pooled, pressure dialyzed with buffer $\mathrm{B}$, concentrated and stored at $-70^{\circ} \mathrm{C}$. The fraction that had peak enzymatic activity was the source of enzyme used in subsequent experiments described in this report.

Enzymatic Assay

The reaction mixture consisted of $1.5 \mu \mathrm{mol}$ of an appropriate buffer (see Table 2), $0.7 \mu \mathrm{mol}$ of $\mathrm{MgCl}_{2}, 55 \mathrm{nmol}$ of dithiothreitol, all together in $20 \mu \mathrm{l}$ at a specific $\mathrm{pH}, 20 \mathrm{nmol}$ of $\left(2-{ }^{3} \mathrm{H}\right)$ ATP (specific activity, $60 \mu \mathrm{Ci} / \mu \mathrm{mol}$ ) or one of the other tritium-labelled nucleotide triphosphates (GTP, TTP, CTP and UTP) in $5 \mu \mathrm{l}, 10 \mu \mathrm{l}$ of a solution containing a specific concentration of an aminoglycoside antibiotic and $25 \mu \mathrm{l}$ of the purified enzyme added after chilling the reaction mixture in ice-water, in a total volume of $60 \mu \mathrm{l}$. After incubation for various periods of time at $37^{\circ} \mathrm{C}$, a sample of $50 \mu 1$ was analyzed for enzymatic activity as described previously ${ }^{3}$.

The relative efficiency of nucleotide triphosphates as co-substrates, was determined by equating the largest amount of the drug modified after terminating the reaction in the linear range of assay, to $100 \%$ efficiency. The requirement of divalent cations was similarly determined by using $1.25 \mathrm{nmol}$ of the drug and $0.35 \mu \mathrm{mol}$ of one of the cations, namely, $\mathrm{Mg}^{++}, \mathrm{Mn}^{++}, \mathrm{Zn}^{++}, \mathrm{Ca}^{++}$and $\mathrm{Ni}^{++}$and a buffer adjusted to a $\mathrm{pH}$ that was optimal for adenylylation (see Table 2). Amikacin and dibekacin were adenylylated at $\mathrm{pH} 6.0$ to avoid precipitation of the components of the reaction mixture occurring at higher $\mathrm{pH}$.

$\mathrm{Km}$ values were obtained from LINEWEAVER-BURK plots.

Isoelectric Focusing

A solution of $1 \%$ Ampholine (LKB-Produkter, Bromma, Sweden) with a $\mathrm{pH}$ range of $3.5 \sim 10.0$ in a glycerol gradient $(0 \sim 60 \%)$ containing $0.1 \mathrm{~mm}$ dithiothreitol was pumped into a $110 \mathrm{ml}$ column (LKB $8100-1$ ) at $4^{\circ} \mathrm{C}$, according to the manufacturer's instructions, with the anode being at the top of the column. The $\mathrm{pH}$ gradient was allowed to form by electrofocusing for 48 hours at $1,000 \mathrm{~V}$ and $3 \mathrm{~mA}$. One $\mathrm{ml}$ of the enzyme was applied to the column and electrofocusing continued for 16 hours.

\section{Estimation of Molecular Weight by Gel-filtration}

The molecular weight of the purified enzyme was estimated by the method described by ANDREws $^{4}$. One $\mathrm{ml}$ of the enzyme $(1.4 \mathrm{mg}$ protein) was applied to a $2.5 \times 45 \mathrm{~cm}$ column packed with Sephadex G-100 and eluted upwards with buffer B at a flow rate of $12 \mathrm{ml} /$ hour. The molecular weight of the enzyme was estimated with reference to the molecular weight of standard proteins such as bovine serum albumin $(66,200)$, ovalbumin $(45,000), \alpha$-chymotrypsinogen $\mathrm{A}(25,100)$ and cytochrome $\mathrm{C}(12,523)$, used at a concentration of $5 \mathrm{mg} / \mathrm{ml}$. 


\section{MIC of Drugs}

The minimal inhibitory concentration of antibiotics was determined in MUELLER-HINTON broth (BBL) according to the standardized method described by ERICSSON and SHERRIS ${ }^{5}$.

Protein Assay

The protein content of the osmotic shockate and the pooled fractions from chromatography was determined by the method of LOWRY et al. ${ }^{6)}$ after dialyzing the samples against double-distilled water to remove substances interfering in the assay.

\section{Results}

\section{Purification of the Enzyme}

Dibekacin affinity chromatography of the shockate yielded the enzymatic activity against tobramycin, butirosin and dibekacin, homogeneously in identical fractions, with the maximum activity being eluted at a concentration of $0.32 \mathrm{M} \mathrm{NaCl}$ (see Fig. 1). Chromatography on DEAE-Sepharose CL-6B of a sample purified by affinity chromatography also yielded the enzymatic activity against the three drugs, homogeneously in identical fractions, with the maximum activity being eluted at a concentration of $0.25 \mathrm{M} \mathrm{NaCl}$. The specific activity of the shockate increased from 110 units to 194 units after purification by affinity chromatography (see Table 1). A further increase to 457 units was obtained following chromatography on DEAE-Sepharose CL-6B with a concomitant yield of $150 \%$ of the initial activity. Purification of the enzyme by tobramycin affinity chromatography, followed by chromatography on DEAE-Sepharose CL-6B, gave a similar degree of purification (see Table 1). The final yield, however, was only $24 \%$ of the initial activity. The homogeneity of the purified enzyme sample was examined further by isoelectric focusing and by gel-filtration on Sephadex G-100. The enzyme appeared homogeneously in a narrow zone around $\mathrm{pH} 5.0$, after isoelectric focusing, having adenylylating activity against tobramycin, butirosin and dibekacin. Gel-filtration on Sephadex G-100 also yielded adenylylating activity against tobramycin, butirosin and dibekacin, homogeneously in identical fractions. The molecular weight of the enzyme was estimated to be 46,770 in gelfiltration with reference to the mobility of proteins of known molecular weight.

No significant loss of activity was discernible in the purified en-

Fig. 1. Elution profile of ANT $\left(4^{\prime}, 4^{\prime \prime}\right)$ from dibekacin affinity chromatography. The fractions were tested for enzymatic adenylylation of $2.5 \mathrm{nmol}$ each of tobramycin, butirosin and dibekacin. The reaction was terminated after 8,12 , and 15 minutes of incubation at $37^{\circ} \mathrm{C}$, respectively.

$(-)$ Absorbance at $280 \mathrm{~nm} ;\left(\mathrm{O}_{-0}\right)$ adenylylation of tobramycin in citrate phosphate buffer at pH 5.0; - - adenylylation of dibekacin in Tris-maleate buffer at $\mathrm{pH}$ 7.5. The elution profile of adenylylating activity against butirosin, tested in citrate phosphate buffer at pH 5.5, was identical to that of dibekacin.

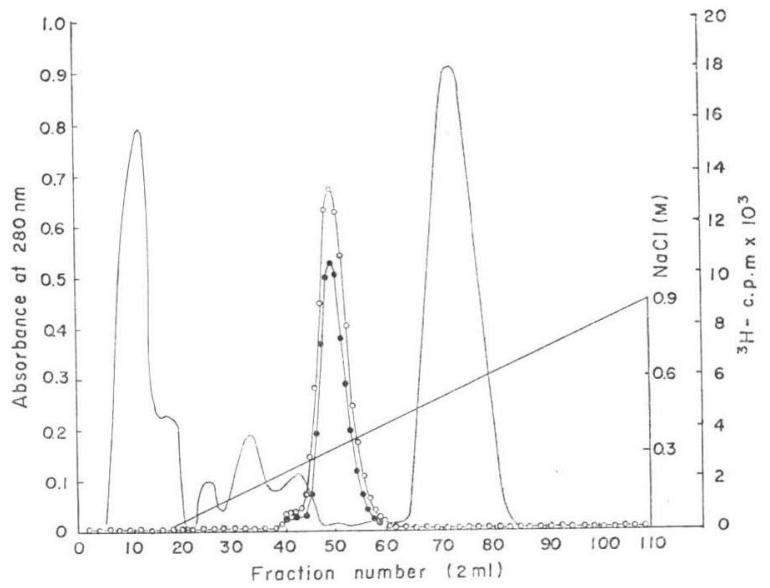


Table 1. Purification of aminoglycoside $4^{\prime}, 4^{\prime \prime}$-nucleotidyltransferase

\begin{tabular}{|c|c|c|c|c|c|c|}
\hline & \multicolumn{2}{|c|}{ Units $\left.^{a}\right)$} & \multicolumn{2}{|c|}{$\begin{array}{l}\text { Specific activity } \\
\text { (u/mg protein) }\end{array}$} & \multicolumn{2}{|c|}{$\begin{array}{c}\text { Recovery } \\
(\%)\end{array}$} \\
\hline & $\mathrm{Dib}^{\mathrm{b}}$ ) & $\mathrm{Tob}^{\mathbf{c})}$ & Dib & Tob & Dib & Tob \\
\hline Shockate & 4970 & 6732 & 110 & 42 & 100 & 100 \\
\hline $\begin{array}{l}\text { Affinity } \\
\text { chromatography }\end{array}$ & 8316 & 2931 & 194 & 81 & 170 & 44 \\
\hline $\begin{array}{l}\text { DEAE-Sepharose } \\
\text { chromatography }\end{array}$ & 7194 & 1614 & 457 & 152 & 150 & 24 \\
\hline
\end{tabular}

a) One unit of enzyme is defined as the amount required to catalyse the adenylylation of $0.1 \mathrm{nmol}$ of tobramycin per minute, under optimal conditions, as described in Materials and Methods.

b) $\mathrm{Dib}=$ dibekacin.

c) $\mathrm{Tob}=$ tobramycin.

zyme samples stored at $-70^{\circ} \mathrm{C}$, even after 5 months.

Nucleotidylation of Aminoglycosides

Of the aminoglycoside antibiotics tested (see Table 2), only those that had an equatorially oriented hydroxyl group either at the $4^{\prime}$-position or at the $4^{\prime \prime}$-position or at both the positions (see Fig. 3) were found to be adenylylated by the enzyme. Each of the substrates, tested at a concentration of $2.5 \mathrm{nmol}$, had a specific optimal $\mathrm{pH}$ for adenylylation (see Table 2). The $\mathrm{pH}$ curves for neomycin B and paromomycin, however, showed 2 characteristic peaks around $\mathrm{pH} 5.0$ and 9.0, with the adenylylation occurring faster in the first peak than in the second. Adenylylation resulted in inactivation of all the substrates (see Table 2). The efficiency of each antibiotic, as a substrate for the enzyme at a concentration of $2.5 \mathrm{nmol}$, was estimated by conducting the enzymatic reaction at a $\mathrm{pH}$, that was optimal for adenylylation of the respective substrate (see Table 2). The most efficient substrate was found to be kanamycin

B, followed by tobramycin, while the least efficient one was dibekacin. The significance of the role of the enzyme in the mechanism of resistance to various aminoglycosides is emphasized by the MIC of butirosin and 4'deoxybutirosin. While butirosin, being a substrate for the enzyme, had a MIC of $200 \mu \mathrm{g}$ / ml (see Table 2), 4'deoxybutirosin had a MIC of only $3.13 \mu \mathrm{g} / \mathrm{ml}$. The latter being a non-
Fig. 2. The time-course of adenylylation by a sample of ANT (4', 4") purified by affinity chromatography and by DEAE-Sepharose chromatography.

(A) adenylylation of $2.5 \mathrm{nmol}$ each of kanamycin B (•-) and dibekacin (०--- $)$ in citrate phosphate buffer and Tris-maleate buffer at pH 5.0 and 7.5 respectively. (B) adenylylation of $2.5 \mathrm{nmol}$ of tobramycin-4'-AMP in citrate phosphate buffer at $\mathrm{pH} 7.0(0-0)$.
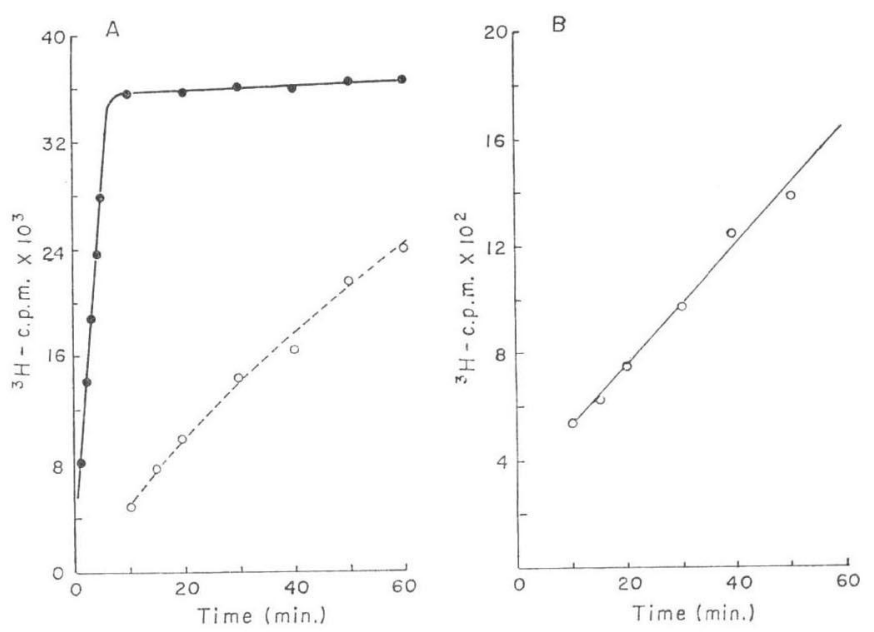
Table 2. Adenylylation of aminoglycoside antibiotics by aminoglycoside 4', 4'-nucleotidyltransferase.

\begin{tabular}{|c|c|c|c|c|}
\hline Drug & $\begin{array}{l}\text { Optimum } \mathrm{pH}^{\mathrm{a})} \\
\text { for } \\
\text { adenylylation }\end{array}$ & $\begin{array}{c}\text { Relative }{ }^{\mathrm{b})} \\
\text { efficiency of } \\
\text { adenylylation } \\
(\%)\end{array}$ & $\begin{array}{c}\mathrm{MIC} \\
(\mu \mathrm{g} / \mathrm{ml})\end{array}$ & $\begin{array}{l}\left.\text { Residual }^{\circ}\right) \\
\text { antibacterial } \\
\text { activity }(\%)\end{array}$ \\
\hline Kanamycin B & 5.0 & 100 & 200 & 0 \\
\hline Tobramycin & 5.0 & 95 & 200 & 0 \\
\hline Neomycin C & 5.0 & 78 & 100 & 0 \\
\hline Ribostamycin & 5.0 & 61 & $>400$ & 0 \\
\hline Neomycin B & 4.5 & 42 & 6.25 & 0 \\
\hline Butirosin $(A+B)$ & 5.5 & 37 & 200 & 0 \\
\hline Paromomycin & 5.0 & 33 & 100 & 0 \\
\hline Lividomycin B & 5.0 & 31 & 400 & 0 \\
\hline Kanamycin C & 5.5 & 28 & 400 & 0 \\
\hline Gentamicin B & 6.0 & 27 & 50 & 0 \\
\hline Kanamycin A & 5.5 & 26 & 100 & 0 \\
\hline Gentamicin A & 5.5 & 24 & 400 & 0 \\
\hline Amikacin & 6.5 & 12 & 6.25 & 0 \\
\hline Lividomycin A & 6.0 & 12 & 3.13 & 0 \\
\hline $3^{\prime}, 4^{\prime}$-Dideoxykanamycin B & 7.5 & 6 & 6.25 & 0 \\
\hline Streptomycin B & - & - & $>400$ & 100 \\
\hline Streptomycin & - & - & $>400$ & 100 \\
\hline Spectinomycin & - & - & 25 & 100 \\
\hline $4^{\prime}$-Deoxybutirosin & - & - & 3.13 & 100 \\
\hline Apramycin & - & - & 0.78 & 100 \\
\hline Sisomicin & - & - & $<0.05$ & 100 \\
\hline Gentamicin $\mathrm{C}_{1}, \mathrm{C}_{1 \mathrm{a}} \& \mathrm{C}_{2}$ & - & - & $<0.05$ & 100 \\
\hline
\end{tabular}

a) The reaction mixture for determination of optimum $\mathrm{pH}$ for adenylylation of different drugs, consisted of $2.5 \mathrm{nmol}$ of drug together with the ingredients described in Materials and Methods. The reaction was terminated after incubation for $3 \sim 8$ minutes at $37^{\circ} \mathrm{C}$ depending on the relative efficiency of the drug as a substrate. Incorporation of ${ }^{3} \mathrm{H}$-AMP in the drug between $\mathrm{pH} 4.0 \sim 7.0$ in citrate phosphate buffer, between pH 5.5 8.0 in Tris-maleate buffer, between $\mathrm{pH} 7.5 \sim 9.0$ in Tris- $\mathrm{HCl}$ buffer, and between $\mathrm{pH} 8.5 \sim 10.0$ in glycine- $\mathrm{NaOH}$ buffer, was determined as described previously. ${ }^{1,3)}$ Optimal adenylylation of those drugs between $\mathrm{pH} 4.5 \sim 6.5$ was in citrate phosphate buffer, at $\mathrm{pH} 7.5$ in Tris-maleate buffer and at $\mathrm{pH} 9.0$ in glycine- $\mathrm{NaOH}$ buffer.

b) The experiment was performed as described in Materials and Methods, at the corresponding optimal $\mathrm{pH}$ for adenylylation. The $\mathrm{pH}$ of the reaction mixture for neomycin $\mathrm{B}$ and paromomycin was 4.5 and 5.0 respectively. The reaction was terminated in the linear range of adenylylation after 4 minutes of incubation. One hundred percent efficiency amounted to $595 \mathrm{pmol}$ of kanamycin B adenylylated.

c) The residual antibacterial activity was tested as described previously. ${ }^{1}$

substrate, is not inactivated by the enzyme. In general, there appeared to be a close correlation between the MIC of the drugs and their relative efficiency as substrates for the enzyme, excepting neomycin B, amikacin, lividomycin A and dibekacin, which had a low MIC although they were inactivated by the enzyme in vitro.

Of the nucleotide-triphosphates tested, the purine nucleotide triphosphates (ATP and GTP), were found to be more efficient as co-substrates of the aminoglycosides for nucleotidylation, than the pyrimidine nucleotide triphosphates (TTP, UTP and CTP). The latter hardly served as co-substrates, excepting for kanamycin B, tobramycin, neomycins B and C and paromomycin. Paromomycin was the only substrate found to be nucleotidylated more efficiently with UTP than with ATP and GTP. 
Fig. 3. (A) Structure of the kanamycins. Tobramycin is $3^{\prime}$-deoxykanamycin B (ring I) and dibekacin is $3^{\prime}, 4^{\prime}$-dideoxykanamycin B (ring I). Arrows indicate sites of adenylylation by ANT (4', 4').

(B) Structure of the gentamicins. Sisomicin is $4^{\prime}, 5^{\prime}$-dehydrogentamicin $\mathrm{C}_{1_{\mathrm{a}}}$ (ring I). Arrow indicates the site of adenylylation of gentamicin A and B by ANT $\left(4^{\prime}, 4^{\prime \prime}\right)$.

(C) Structure of the neomycins and lividomycins. Arrows indicate the possible sites of adenylylation by ANT (4', 4').

(D) Structure of ribostamycin and the butirosins. Arrow indicates the site of adenylylation by ANT $\left(4^{\prime}, 4^{\prime \prime}\right)$.
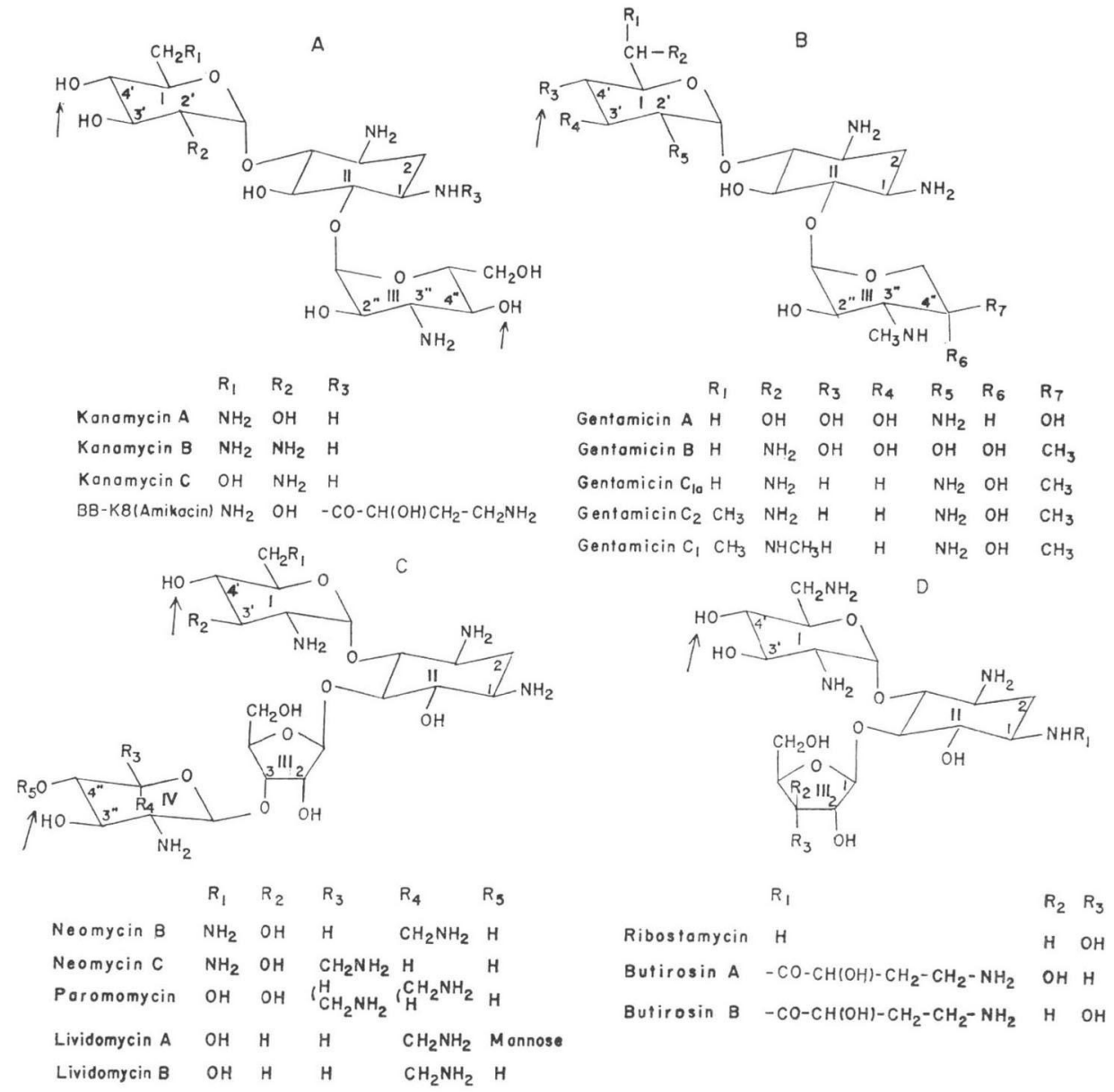

Magnesium was found to be the most efficient cation in the adenylylation of all the substrates excepting kanamycin B, tobramycin, neomycin B and neomycin C, which were adenylylated most efficiently in the presence of $\mathrm{Mn}^{++}$. Adenylylation was barely detectable in the presence of Ca++. Excepting gentamicin B, none of the substrates was adenylylated in the presence of $\mathrm{Ni}^{++}$. Adenylylation in the presence of $\mathrm{Zn}^{++}$was, comparatively, rather poor.

The $K m$ values for ribostamycin and amikacin, obtained from LINEWEAVER-BURK plots, were $68.9 \mu \mathrm{M}$ and $660 \mu \mathrm{M}$ respectively, indicating a stronger affinity to the enzyme's catalytic site of the former than the latter. Due to substrate inhibition, $K m$ values for the rest of the substrates could not be determined. 


\section{Discussion}

The experimental results presented in this report, together with the analyses of the ${ }^{13} \mathrm{C}-\mathrm{NMR}$ spectra of the adenylylated aminoglycosides made recently ${ }^{i)}$, reveal that the aminoglycoside nucleotidyltransferase from Staphylococcus epidermidis FK109 catalyzes the transfer of the nucleotide monophosphate moiety from nucleotide triphosphates, to the equatorial hydroxyl group at the 4 '- and $4^{\prime \prime}-$ positions of the aminoglycoside antibiotics (see Fig. 3). A comparison of the spectra of tobramycin and adenylyl-tobramycin clearly demonstrated that $\mathrm{C}\left(4^{\prime}\right)$ was the centre to which the phosphate bond was linked, because only the signals of $\mathrm{C}\left(3^{\prime}\right), \mathrm{C}\left(4^{\prime}\right)$ and $\mathrm{C}\left(5^{\prime}\right)$ were split and shifted. In the case of dibekacin the resonances of $\left(\mathrm{C}^{\prime \prime}\right),\left(\mathrm{C}^{\prime \prime}\right)$ and $\mathrm{C}\left(5^{\prime \prime}\right)$ were split and shifted, indicating that adenylylation had taken place at the equatorial $4^{\prime \prime}$-hydroxyl group. The designation of the enzyme viz., ANT $\left(4^{\prime}, 4^{\prime \prime}\right)$, therefore, seems appropriate.

Purification of the enzyme by dibekacin affinity chromatography (see Fig. 1) followed by chromatography on DEAE-Sepharose CL-6B, yielded a recovery of $170 \%$ of the initial activity (see Table 1), which probably denotes elimination of inhibitors of the enzymatic reaction present in the osmotic shockate. The five-fold increase in specific activity achieved by the two steps of purification must be deemed significant, since the osmotic shockate is relatively free from most of the cellular contents that are present in a cell-lysate.

Tobramycin affinity chromatography of ANT $\left(4^{\prime}, 4^{\prime \prime}\right)$ followed by chromatography on DEAESepharose CL-6B also yielded a 5-fold degree of purification (see Table 1). The final recovery after the two steps of purification was, however, only $24 \%$ of that of the initial activity. Tobramycin, being one of the best substrates (see Table 2), obviously binds with the enzyme stronger than dibekacin. A concentration of $0.77 \mathrm{M} \mathrm{NaCl}$ was therefore required to release the maximum amount of enzyme in affinity chromatography, in contrast with $0.32 \mathrm{M} \mathrm{NaCl}$ required in dibekacin affinity chromatography (see Fig. 1). The phenomenon of modification of the active centre of an enzyme by binding of a substrate and subsequent release of the product, resulting in a concomitant loss of its catalytic activity, is well known. The pH 5.5 of the Tris-maleate buffer used for elution of the enzyme bound to tobramycin, might also be a factor contributing to the poor recovery.

The homogeneity of the enzyme, as a single entity, was demonstrated further in isoelectric focusing and in gel-filtration. The enzyme has an isoelectric point of 5.0 and a molecular weight of 46,770. The only other aminoglycoside modifying enzymes having a higher molecular weight are the aminoglycoside 3-N-acetyltransferase [AAC (3)], a tetramer of $\left.63,000,{ }^{8}\right)$ and two types of aminoglycoside $3^{\prime}$-phosphotransferase [APH(3')1], with a molecular weight of 63,000 and 54,000 respectively ${ }^{9}$.

A comparative examination of the time-course of adenylylation of kanamycin $\mathrm{B}$, dibekacin, tobramycin and tobramycin-4'-AMP (see Fig. 2A and 2B) shows that kanamycin B, being a good substrate, is adenylylated completely in 10 minutes from the start of reaction, while an equimolar quantity of dibekacin is adenylylated much slower than kanamycin B, with adenylylation being incomplete even after 60 minutes of reaction. Tobramycin, like kanamycin B, is completely adenylylated in 10 minutes, while adenylylation of tobramycin-4'-AMP proceeds much slower than that of dibekacin (see Fig. 2B). Adenylylation of tobramycin, either at $\mathrm{pH} 5.0$ or at $\mathrm{pH} 7.0$, is not inhibited by tobramycin-4'-AMP even at a ratio of $1: 100$, which excludes the possibility that the time-course curve of enzymatic reaction with tobramycin-4'-AMP might be the result of inhibition of adenylylation of traces of tobramycin present in the mixture. The $4^{\prime}-\mathrm{OH}$ of the substrate molecule, therefore, exhibits a far greater affinity to the enzyme than the $4^{\prime \prime}-\mathrm{OH}$, which is also reflected in the relative efficiency of kanamycin $\mathbf{B}$ and dibekacin as substrates for the enzyme (see Table 2). While the $\mathrm{pH}$ required for optimal adenylylation of tobramycin is 5.0 , the $\mathrm{pH}$ required for dibekacin is 7.5 (see Table 2). An examination of the $\mathrm{pH}$ values for optimal adenylylation of various substrates shows that those drugs that have a hydroxyl group either at the 4'-position alone (butirosin) or at both the 4'- and 4"'-positions (tobramycin) are adenylylated optimally in the acidic range. The latter are preferentially adenylylated at the $4^{\prime}-\mathrm{OH}$ position. ${ }^{7}$ ) Those that have a hydroxyl group only at the 4"-position (dibekacin), are adenylylated optimally in the basic range of $\mathrm{pH}$. The two peaks around pH 5.0 and 9.0 observed in the pH profile of neomycin B and paromomycin (see Table 2), perhaps 
represent optimal adenylylation of the $4^{\prime}$-hydroxyl group and the $4^{\prime \prime}$-hydroxyl group at the two respective $\mathrm{pH}$ values. As a consequence of adenylylation, the substrates lose their antibiotic property (see Table 2). Although there is a general correlation between inactivation of the drugs and their corresponding MIC, a discrepancy arises with neomycin B, lividomycin A, amikacin and dibekacin which exhibit a low MIC although they are inactivated by the enzyme in vitro. DAVIES and BENVENISTE ${ }^{11}$ ) have suggested that resistance to aminoglycoside antibiotics in $E$. coli is not due to "gross inactivation" of the antibiotics. A few of the molecules modified by the enzyme are supposed to block entry of the antibiotic into the cell. The apparent discrepancy observed with the 4 drugs aforementioned, might be due to the inability of the modified molecules to prevent efficiently, entry of the antibiotics into the cell. Alternatively, it might be due to a rate of diffusion of the drugs into the cell, that is faster than the rate of inactivation.

Thus, ANT $\left(4^{\prime}, 4^{\prime \prime}\right)$, by virtue of its ability to adenylylate the 4'-hydroxyl group and the $4^{\prime \prime}-$ hydroxyl group of the aminoglycoside molecule, encompasses a spectrum of substrates which is the broadest of all those known for the aminoglycoside modifying enzymes ${ }^{10,12 \sim 18)}$.

\section{Acknowledgements}

We thank Drs. T. Yokota and H. Kawabe for providing us with dibekacin, Mrs. U. Schwotzer for the purified sample of tobramycin-4'-AMP and Mrs. L. RUEGG for preparing the drawings and the manuscript.

\section{References}

1) Santanam, P. \& F. H. Kayser: Tobramycin adenylyltransferase: A new aminoglycoside-inactivating enzyme from Staphylococcus epidermidis. J. Infect. Dis. 134: S33 39, 1976

2) LeGoffic, F.; A. Martel, M. L. Capmau, B. Baca, P. Goebel, H. Chardon, C. J. Soussy, J. Duval \& D. H. Bouanchaud: New plasmid-mediated nucleotidylation of aminoglycoside antibiotics in Staphylococcus aureus. Antimicr. Agents \& Chemoth. 10: 258 264, 1976

3) Santanam, P. \& F. H. Kayser: Enzymatic adenylylation by aminoglycoside 4'-adenylyltransferase and $2^{\prime \prime}$-adenylyltransferase as a means of determining concentrations of aminoglycoside antibiotics in serum. Antimicr. Agents \& Chemoth. 10: 664 667, 1976

4) Andrews, P.: The gel-filtration behaviour of proteins related to their molecular weights over a wide range. Biochem. J. 96: 595 606, 1965

5) Ericsson, H. M. \& J. C. Sherris: Antibiotic sensitivity testing: Report of an international collaborative study. Acta Pathol. Microbiol. Scand. (B) 79 (Suppl. 217): 1 90, 1971

6) Lowry, O. H.; N. J. Rosenbrough, A. L. FArR \& R. J. Randall: Protein measurement with the Folin phenol reagent. J. Biol. Chem. 193: 265 275, 1951

7) Schwotzer, U.; F. H. KAyser \& W. Schwotzer: R-Plasmid mediated aminoglycoside resistance in Staphylococcus epidermidis: Structure determination of the products of an enzyme, nucleotidylating the 4'- and 4"'-hydroxyl groups of aminoglycoside antibiotics. FEMS Microbiol. Letters 3: 29 33, 1978

8) Williams, J. W. \& D. B. Northrop: Purification and properties of gentamicin acetyltransferase. Biochemistry (U.S.A.) 15: $125 \sim 131,1976$

9) Matsuhashi, Y.; M. Yagisawa, S. Kondo, T. Takeuchi \& H. Umezawa: Aminoglycoside 3'-phosphotransferases I and II in Pseudomonas aeruginosa. J. Antibiotics 28: 442 447, 1975

10) HaAs, M. J. \& J. E. Dowding: Aminoglycoside-modifying enzymes. pp. $611 \sim 628$ in J. H. Hash (ed.), Methods in Enzymology, Volume 43, Antibiotics. Academic Press, New York, 1975

11) Davies, J. E. \& R. E. Benveniste: Enzymes that inactivate antibiotics in transit to their targets. Ann. N.Y. Acad. Sci. 235: 130 136, 1974

12) Kawabe, H.; S. Kondo, H. Umezawa \& S. Mitsuhashi: R Factor-mediated aminoglycoside antibiotic resistance in Pseudomonas aeruginosa: A new aminoglycoside 6'-N-acetyltransferase. Antimicr. Agents \& Chemoth. 7: 494 499, 1975

13) Kayser, F. H.; M. Devaud \& J. Biber: Aminoglycoside 3'-phosphotransferase IV: a new type of aminoglycoside-phosphorylating enzyme found in staphylococci. Microbios Letters 3: 63 68, 1976

14) Matsuhashi, Y.; T. Sawa, T. Takeuchi \& H. Umezawa: Purification of aminoglycoside 3 '-phosphotransferase II. J. Antibiotics 29: 204 207, 1976

15) Suzuki, I.; N. Takahashi, S. Shirato, H. Kawabe \& S. Mitsuhashi: Adenylylation of streptomycin by Staphylococcus aureus: A new streptomycin adenylyltransferase. pp. $463 \sim 473$. In S. MrTsUHASHI \& 
H. НаSнimoto (ed.), Microbial drug resistance. University Park Press, Baltimore, 1975

16) Umezawa, Y.; M. Yagisawa, T. Sawa, T. Takeuchi \& H. Umezawa: Aminoglycoside 3'-phosphotransferase III, a new phosphotransferase. J. Antibiotics 28: 845 853, 1975

17) Umezawa, H.; H. Yamamoto, M. Yagisawa, S. Kondo \& T. Takeuchi: Kanamycin phosphotransferase I: Mechanism of cross resistance between kanamycin and lividomycin. J. Antibiotics 26: 407 411,1973

18) Yagisawa, M.; H. Yamamoto, H. Naganawa, S. Kondo, T. Takeuchi \& H. Umezawa: A new enzyme in Escherichia coli carrying R-factor phosphorylating 3'-hydroxyl of butirosin A, kanamycin, neamine and ribostamycin. J. Antibiotics 25: 748 750, 1972 